Andragogi: Jurnal Ilmiah Pendidikan Agama Islam http://riset.unisma.ac.id/index.php/ja/issue/view $\underline{1696}$

Volume 2 Nomor 2 Tahun 2020

e-ISSN: 2655-948X

http://u.lipi.go.id/1548306171

\title{
KORELASI ANTARA MEDIA SOSIAL DAN KONSEP DIRI DENGAN MAHASISWA PENDIDIKAN AGAMA ISLAM
}

\author{
Achmad Farid \\ Pendidikan Agama Islam Universitas Sunan Kalijaga Yogyakarta \\ e-mail: faridSN14@yahoo.co.id
}

Diterima: 28 September 2020 | Direvisi: 23 November 2020 | Disetujui: 27 November 2020

(C) 2018 Program Studi Pendidikan Agama Islam Fakultas Agama Islam Universitas Islam Malang

\begin{abstract}
PAI students are required to have good religiosity values in every aspect. However, in reality there are still many PAI students who have not met the criteria for religiosity. The purpose of this study was to improve the quality of Islamic Education students by correlating social media and self-concept. This research is a library research. The analysis obtained in this study is that PAI students can learn Islamic religious sciences more widely, and preach their knowledge through social media. But apart from positive influences, social media also has negative influences. So that to increase the religiosity of PAI students requires a self-concept. Self-concept is a view or assessment, as well as an introduction to oneself. By having a good self-concept, PAI students can realize that they are studying Islamic religious sciences which apart from being required to understand, are also required to practice it to others. So that their mindset is no longer just a mere value or diploma. So with this correlation it can improve the quality of PAI students for the better.
\end{abstract}

Keywords: social media, self-concept, PAI students

\begin{abstract}
Abstrak
Mahasiswa PAI dituntut untuk memiliki nilai-nilai religiusitas yang baik dalam setiap aspeknya. Namun realitanya masih banyak ditemukan mahasiswa PAI yang belum memenuhi kriteria religiusitas tersebut. Tujuan penelitian ini adalah untuk meningkatkan kualitas mahasiswa PAI dengan mengkorelasikan antara media sosial dan konsep diri. Penelitian ini merupakan penelitian kepustakaan. Analisis yang diperoleh dalam penelitian ini adalah mahasiswa PAI dapat belajar ilmu-ilmu agama Islam dengan lebih luas, dan berdakwah mengamalkan kembali ilmu-ilmunya tersebut melalui media sosial. Namun selain pengaruh positif, media sosial juga memiliki pengaruh negatif. Sehingga untuk meningkatkan religiusitas mahasiswa PAI memerlukan konsep diri. Konsep diri adalah pandangan atau penilaian, serta pengenalan terhadap diri sendiri. Dengan memiliki konsep diri yang baik mahasiswa
\end{abstract}

This work is licensed under Creative Commons Attribution Non Commercial 4.0 International License Available online on: http://riset.unisma.ac.id/index.php/fai/index 
PAI dapat menyadari bahwa ia sedang mempelajari ilmu-ilmu agama Islam yang selain dituntut untuk paham, juga dituntut untuk mengamalkannya kepada orang lain. Sehingga mindset mereka bukan lagi hanya sebatas nilai atau ijazah belaka. Maka dengan korelasi ini dapat meningkatkan kualitas mahasiswa PAI menjadi lebih baik.

Kata Kunci: media sosial, konsep diri, mahasiswa PAI

\section{Pendahuluan}

Hegemoni Barat terhadap masyarakat Indonesia semakin menjalar (Hidayatullah MF, 2019: 210), mengingat saat ini negara dan masyarakatnya dihadapkan dengan perkembangan ilmu pengetahuan dan teknologi, termasuk mahasiswa PAI yang mendapatkan dampak dari perkembangannya. Pendidikan agama Islam adalah pembelajaran mengenai ilmu-ilmu keislaman ataupun materimateri yang dimuat dalam pembelajaran PAI, yang itu merupakan suatu kewajiban bagi setiap muslim. Baik ketika pembelajaran tersebut dilaksanakan di lembaga pendidikan seperti sekolah dan universitas, maupun di luar daripada itu (Zuhairini, 2014: 11). Pembelajaran PAI disebut juga sebagai pembelajaran yang bersumber kepada Al-Quran dan Hadis, yang bertujuan agar menjadi bertakwa dan menciptakan akhlak yang mulia (Kemenag RI, 2010: 17).

Adapun religiuisitas, adalah kombinasi yang lengkap antara pengetahuan, rasa (keyakinan), serta perilaku agama seseorang (Jalaluddin, 1966: 133). Derajat keagamaan seseorang dapat dilihat dari bagaimana ia menjalankan dimensi religiusitas tersebut (Stark dan Glock, 1995: 295). Apresiasi masyarakat dan pengamalan ajaran Islam sangat tergantung pada kualitas ajaran Islam yang diterimanya. PAI pada dasarnya adalah pendidikan yang bertujuan membentuk seluruh umat Islam dan mengembangkan segenap potensi manusia lahir dan batin (Saidah, 2007: 5).

Pertumbuhan pemikiran agama seseorang bertepatan dengan pertumbuhan kecerdasan yang dimiliki. Perkembangan kemampuan kognitif memungkinkan seseorang untuk meninggalkan keyakinan serta pengetahuan agama sebelumnya yang diperoleh dari lingkungan, kemudian mulai memikirkan konsep, dan bergerak menuju keyakinan pribadi yang sejati pada agama (Sururin, 2004: 67). Menurut hasil penelitian Khudiatul Chairuni tentang pendidikan dan pembelajaran Islam aktif telah mempengaruhi keyakinan beragama siswa SMP Bakti Mulya 400 Jakarta, dengan data 34\%, dan 66\% dampaknya dipengaruhi oleh faktor lain (Chairuni, 2019: 61). Penelitian ini menunjukkan bahwa pendidikan agama sangat penting untuk meningkatkan keberagamaan seseorang. Pendidikan agama di Indonesia 
memiliki posisi yang sangat strategis, mengingat Indonesia adalah negara yang religius, maka agama dijadikan sebagai modal dasar pembangunan di Indonesia dan menjadi motor penggerak bagi warganya untuk menuju kehidupan yang lebih baik dan sempurna. Agama sebagai pengendali, penuntun dan pembimbing (Sabri, 1999: 74). Karakter religius bisa akan kuat terhadap diri manusia ketika dimulai dari bimbingan keluaraga atau orang tua, didikan yang dilakukan mulai kecil menjadi modal besar untuk menjadikan manusia dewasa yang sangat religius (Safi'i, 2017).

Dalam pandangan ahli, religiusitas memiliki beberapa aspek atau dimensi, namun setidaknya ada tiga dimensi besar di dalam religiusitas, yaitu pengetahuan agama, tingkah laku (akhlak), dan pengamalan ilmu agama. Namun berdasarkan tiga dimensi tersebut masih banyak ditemukan mahasiswa PAI yang masih minim perannya dalam tiga dimensi itu. Dari pengetahuan misalnya, masih banyak mahasiswa PAI yang malas untuk belajar atau membaca buku, ketika sedang berdiskusi atau belajar di kelas, banyak dari mereka yang hanya bisa diam, jarang bertanya dan sebagainya. Sehingga pengetahuannya tentang ilmu-ilmu agama masih kurang mendalam. Berbeda dengan mahasiswa alumni pondok yang sudah lama dan lebih dulu mempelajari ilmu-ilmu agama, sedangkan mahasiswa yang berasal dari sekolah umum itulah realita yang terjadi di lapangan.

Kemudian dari tingkah laku, mahasiswa PAI seyogyanya dituntut untuk memiliki akhlak yang baik, namun terbentuknya akhlak atau tingkah laku pun tergantung dari bagaimana cara mereka berpikir, sehingga ilmu-ilmu agama Islam sangat penting untuk dipelajari secara mendalam. Sampai mereka memahami betul betapa pentingnya akhlak atau adab, bahkan dibandingkan ilmu. Kemudian dalam aspek pengamalan, banyak ditemukan mahasiswa PAI yang memiliki nilai akademik yang tinggi, namun masih minim perannya dalam masyarakat, atau dalam mengamalkan ilmu-ilmunya tersebut. Karena tujuan dari belajar ilmu agama Islam adalah untuk diri sendiri lalu diajarkan kepada orang lain. Demikian esensi ajaran Islam.

\section{Metode}

Jenis penelitian ini adalah penelitian kepustakaan (library research), yaitu penelitian yang digunakan untuk memecahkan masalah teori konseptual. Singkatnya, studi pustaka adalah suatu penelitian yang berupaya mengumpulkan data dari berbagai literatur dan menjadikannya sebagai objek utama analisis. Dalam penelitian ini penulis ingin mengkaji dan menganalisis korelasi antara media sosial dan konsep diri dengan mahasiswa PAI. 


\section{Hasil dan Pembahasan}

\section{Media Sosial}

Melihat pentingnya tiga dimensi religiusitas tersebut pada mahasiswa PAI, maka dapat diatasi dengan adanya media sosial. Selain belajar di kelas, mahasiswa PAI dapat belajar agama melalui media sosial. Sehingga pengetahuan tentang ilmuilmu agama Islam menjadi terus bertambah. Dengan ilmu-ilmu agama yang baik maka dapat mempengaruhi tingkah laku keagamaannya menjadi lebih baik. Menurut Hana, "Seiring berjalannya internet, perkembangan media sosial pun merambat luas di masyarakat mulai dari anak usia sekolah dasar hingga dewasa (Hana dkk, 2017: 77)."

Pembelajaran ilmu agama Islam di era modern ini telah memperlihatkan banyak sekali yang diupload melalui media sosial. Belajar ilmu agama Islam melalui media sosial dapat menjadi alternatif atau sebagai tambahan dari pembelajaran di kelas. Teknologi dapat menjadi faktor eksternal/luar yang dapat mempengaruhi minat belajar peserta didik. Hasil penelitian Ibdalsyah dkk mengungkapkan bahwa:

Media sosial dapat mengembangkan dan meningkatkan konten pembelajaran. Pengguna dapat menggunakan sarana ini dengan berbagai manfaatnya untuk memberikan kontribusi yang positif. Salah satu kegunaan terpenting dari jejaring sosial adalah kemampuan untuk mengatur pembelajaran dengan menghubungkan berbagai ahli untuk berbagi pengetahuan, kegiatan, konsep, dll (Ibdalsyah dkk, 2019: 399).

Sedangkan menurut Hatta dalam penelitiannya menunjukkan fakta bahwa:

Antusiasme remaja muslim Indonesia untuk mempelajari dan "mengaji" ilmu agama di media sosial menunjukkan bahwa di era globalisasi saat ini, dengan perkembangan teknologi, gejala itu terus meningkat. Asumsi ini didasarkan pada sejumlah data survei dan penelitian tentang peningkatan jumlah pengguna Internet. Karena mayoritas penduduk Indonesia adalah Muslim, diduga kuat bahwa remaja yang paling banyak mengakses Internet adalah remaja Muslim (Hatta, 2018: 1).

Dampak dari kemajuan teknologi saat ini, sikap dan perilaku keagamaan anak muda zaman sekarang sebagian besar meningkat dengan adanya kajian-kajian agama di media sosial. Mulai banyak para da'i muda inspiratif bermunculan. Hampir di setiap tempat kajian agama, seperti di masjid, universitas/kampus, dan tempat lainnya, sebagian besar diikuti oleh anak-anak muda. Berbeda dengan beberapa tahun yang lalu sebelum media sosial secanggih sekarang, kajian-kajian agama biasanya sepi, dan sangat sedikit dari kalangan anak muda.

Selain mendapatkan belajar tambahan melalui media sosial, mahasiswa PAI juga dapat mengamalkan kembali ilmu-ilmu yang dimiliki tersebut di media sosial. 
Ini adalah zaman modern, banyak cara untuk seseorang belajar dan mengajar. Salah satunya melalui media sosial.

Namun media sosial ibarat "Pedang Bermata Dua", selain mempunyai pengaruh dan manfaat yang baik, media sosial juga mempunyai pengaruh-pengaruh negatif. Salah satu pengaruh baik dari media sosial seperti dijelaskan di awal yaitu untuk belajar ilmu agama Islam. Adapun pengaruh buruk dari media sosial seperti banyaknya berita-berita negatif, berita burung, hate speech, dan banyaknya kontenkonten negatif seperti pornografi/aksi yang dapat diakses dengan mudah. Melihat ini, dampak baik atau buruk dari media sosial sesungguhnya dapat mempengaruhi religiusitas seseorang. Namun sesungguhnya dampak atau pengaruh baik dan buruknya tergantung dari individu yang menggunakan. Sehingga untuk dapat mempertahankan serta meningkatkan religiusitas, mahasiswa PAI perlu memiliki "Konsep Diri".

\section{Konsep Diri}

Konsep diri dapat didefinisikan dengan cara seseorang berpikir tentang dirinya sendiri. Sudut pandang konsep diri setidaknya mencakup tiga aspek, yaitu pengetahuan diri, kemudian harapan atau impian diri, dan penilaian diri. Kesimpulan dari pengertian tersebut adalah seseorang mampu mengevaluasi diri mereka sendiri. Konsep diri dapat menjadi faktor internal dari keberhasilan atau prestasi belajar seseorang (Subaryana, 2015: 22).

Kemandirian untuk belajar juga penting dalam proses menuju keberhasilan belajar. Disebutkan bahwa untuk mencapai kesuksesan seseorang tidak selalu bergantung kepada IQ (Intelligence Quotient), atau EI (Emotional Intelligence), melainkan juga diperlukan AQ (Adversity Quotient). Adversity quotient adalah kemampuan seseorang untuk menghadapi dan mengatasi masalah, hambatan atau kesulitan yang dihadapi dan mengubahnya menjadi peluang untuk sukses. Adversity Quotient termasuk dalam aspek konsep diri.

Hairina dan Suharnan mengungkapkan dalam penelitiannya bahwa terdapat korelasi positif antara konsep diri (X1) dan kemandirian siswa (Y) dengan data 60,4\%. Artinya semakin tinggi konsep diri siswa maka semakin tinggi kemandirian belajar siswa, sebaliknya semakin rendah konsep diri siswa maka semakin rendah kemandirian belajarnya (Hairina, 2013: 626).

Sederhananya konsep diri adalah pengetahuan tentang karakter, kemampuan, dan perilaku seseorang. Dengan memiliki konsep diri yang baik, mahasiswa PAI akan mengerti bahwa dengan berada dan menempuh pendidikan di jurusan keagamaan seperti Tarbiyah atau yang lainnya bukanlah sebuah jaminan dapat menjadi orang yang baik dengan begitu saja, terlebih memiliki nilai-nilai religiusitas 
yang tinggi. Kalau tidak diimbangi dengan konsep diri yang tinggi pula. Oleh karena itu, mahasiswa yang tingkat religiusitasnya tinggi adalah mahasiswa yang memiliki kepribadian yang terikat erat dengan agama yang diyakininya. Pemahaman dan keyakinan ini yang menjadikan mahasiswa akan bersikap positif dari hasil konsep diri yang positif pula (Alrieza, 2013: 4).

Namun konsep diri juga dapat diartikan sebagai pemahaman tentang diri sendiri yang timbul dari interaksi dengan orang lain. Konsep diri merupakan faktor penentu (determinan) komunikasi kita dengan orang lain. Konsep diri adalah persepsi dan perasaan diri sendiri. Persepsi diri ini bisa bersifat psikologis, sosial dan fisik (Jalaludin, 2015: 98).

Sebuah jurnal mengatakan bahwa diri memiliki dua arti yang berbeda. Sikap, perasaan, persepsi, dan evaluasi semuanya mengambil diri sebagai objek, sementara pemikiran, observasi, dan aktivitas mengambil diri sebagai proses. Seluruh diri yang dialami individu sering disebut "diri yang fenomenal". Diri yang luar biasa ini adalah diri yang diamati, dialami, dan dinilai oleh individu. Ini adalah diri yang sadar. Jumlah dari semua kesadaran atau persepsi citra dirinya ini adalah konsep dirinya. Konsep diri ini disatukan dalam satu kesatuan yang dinamis. Setiap bagian saling independen dan terkait. Bagian atau keseluruhan ini berinteraksi dengan aspek eksternal dari dunia fenomenal mereka (Pratiwi, 2017: 138).

Korelasi dengan media sosial, seseorang khususnya mahasiswa PAI dengan memiliki konsep diri yang baik, ia akan mengerti bagian mana dari media sosial yang dapat memberikan pengaruh positif bagi dirinya, dan bagian mana yang dapat memberikan pengaruh negatif untuk dirinya. Sebagaimana di awal bahwa media sosial ibarat "Pedang Bermata Dua", ada pengaruh positif dan ada pengaruh negatif. Begitu pula ketika belajar ilmu-ilmu agama Islam, ketika terjadi perbedaan pendapat mengenai suatu hukum misalnya, mahasiswa PAI sudah dapat memahami perbedaan tersebut dan menghindari perdebatan-perdebatan yang dapat mengakibatkan terjadinya konflik.

Konsep diri juga dapat mempengaruhi proses berpikir, perasaan, keinginan, nilai dan tujuan hidup seseorang (Nova, 2012: 59). Seseorang yang memiliki konsep diri yang baik maka akan mudah membimbing dirinya sendiri untuk menjadi lebih baik dan menghindari segala hal yang buruk. Konsep diri juga berbicara mengenai mengenal tentang siapa dirinya sendiri. Dengan konsep diri yang baik maka mahasiswa PAI dapat menyadari bahwa ia sedang mempelajari ilmu-ilmu agama Islam yang selain dituntut untuk paham, ia juga dituntut untuk mengamalkannya kepada orang lain. Sehingga mindset mereka bukan lagi hanya sebatas nilai atau ijazah belaka. 


\section{Simpulan}

Melihat korelasi antara media sosial dan konsep diri dengan mahasiswa PAI, setidaknya dapat meningkatkan potensi atau kualitas mahasiswa PAI menjadi lebih baik. Dengan cara meningkatkan aspek-aspek religiusitas yang ada pada dirinya. Melalui media sosial mahasiswa PAI dapat mempelajari ilmu-ilmu agama Islam dengan lebih banyak dan luas, sehingga bertambah ilmu-ilmu agama Islam mereka. Setelah belajar, mahasiswa PAI dapat berdakwah mengamalkan kembali ilmuilmunya tersebut melalui media sosial. Namun media sosial ibarat "Pedang Bermata Dua”, selain memiliki sisi positif, media sosial juga mempunyai banyak pengaruh negatif. Sehingga mahasiswa PAI perlu memiliki konsep diri dalam hidupnya. Dengan konsep diri yang baik mahasiswa PAI dapat mengenal tentang siapa dirinya. Dengan konsep diri yang baik mahasiswa PAI dapat menyadari bahwa ia sedang mempelajari ilmu-ilmu agama Islam yang selain dituntut untuk paham, ia juga dituntut untuk mengamalkannya kepada orang lain. Sehingga mindset mereka bukan lagi hanya sebatas nilai atau ijazah belaka.

\section{Daftar Rujukan}

Anissa, Nova., Agustin Handayani. (2012). "Hubungan Antara Konsep Diri Dan Kematangan Emosi Dengan Penyesuaian Diri Istri Yang Tinggal Bersama Keluarga Suami", Jurnal Psikologi Pitutur, Vol. 1 No.1.

Chairuni, Khudiatul. (2019). "Pengaruh Keaktifan Belajar PAI Terhadap Religiusitas Peserta Didik Di SMP Bakti Mulya 400 Jakarta”, Skripsi, Pendidikan Agama Islam Fakultas Ilmu Tarbiyah Dan Keguruan Universitas Islam Negeri Syarif Hidayatullah Jakarta.

Hatta, M. (2018). "Media Sosial sebagai Sumber keberagamaan Alternatif Remaja dalam Fenomena Cyberreligion", Jurnal Kajian Dakwah dan Kemasyarakatan Vol. 22 No. 1.

Hidayatullah, Muhammad Fahmi. 2019. Pemikiran Ulama' NU Jawa Timur Tentang Ontologi dan Epistimologi Islam Liberal. Jurnal Qolamuna, Volume 4, Nomor 2.

Ibdalsyah, dkk. (2019). "Media Sosial Dan Pengaruhnya Terhadap Kesadaran Beragama Sebagai Akibat Dari Pola Asuh Orang Tua Dan Peran Guru Di Sekolah, Jurnal Pendidikan Islam, Vol. 08 No. 02.

Novilita, Hairina., Suharna. (2013). “Konsep Diri Adversity Quotient Dan Kemandirian Belajar Siswa”, Jurnal Psikologi Vol. 8 No. 1.

Nur Rahmawati, Hana., dkk. (2017). "Hubungan Durasi Penggunaan Media Sosial Dengan Motivasi Belajar Remaja”, Jurnal Keperawatan Jiwa, Vol. 5 No 2. 
Rakhmat, Jalaluddin. (1966). Psikologi Islam. Jakarta: Raja Grafindo.

Rakmat, Jalaludin. (2015). Psikologi Komunikasi. Bandung: Remaja Rosda Karya.

RI, KEMENAG. (2010). Modul Pengembangan Pendidikan Agama Islam pada Sekolah.

Riswandi. (2013). Psikologi Komunikasi. Yogyakarta: Graha Ilmu

Sabri, M. Alisuf. (1999). Ilmu Pendidikan. Jakarta: Pedoman Ilmu Jaya.

Safi'i,Imam. 2017. Pendidikan Agama di Lingkungan Keluarga Guna Membangun Mentalitas Bangsa. Vicratina, Volume 2 Nomor 2.

Saidah, Nur. (2007). "Pendidikan Agama Islam, Problem Dan Tantangannya Sebagai Komponen Mata kuliah Pengembangan Kepribadian (MPK)", Jurnal Pendidikan Agama Islam Vol. IV, No. 1. 1

Sasmitho, Alrieza Mufajri. (2013). "Hubungan Antara Religiusitas Dengan Konsep Diri Mahasiswa Program Studi Bimbingan Dan Konseling Universitas Negeri Yogyakarta Angkatan 2010". Skripsi, Program Studi Bimbingan Dan Konseling Jurusan Psikologi Pendidikan Dan Bimbingan Fakultas Ilmu Pendidikan Universitas Negeri Yogyakarta.

Stark, R., dan C. Y. Glock. (1995). Dimensins of Religiosity, dalam Ronald Robcertson (eds.) Sosiologi of Religion, Terj. Achmad Fedyani Saifuddin, Agama: dalam Analisa dan Interprestasi Sosiologis. Jakarta: PT. Raja Grafindo Persada.

Subaryana. (2015). “Konsep Diri dan Prestasi Belajar”, Jurnal Dinamika Pendidikan Dasar, Vol. 7, No. 2.

Sururin. (2004). Ilmu Jiwa Agama. Cet. ke-1. Jakarta: PT. Raja Grafindo Persada.

Widiarti, Pratiwi Wahyu. (2017). "Konsep Diri (Self Concept) Dan Komunikasi Interpersonal Dalam Pendampingan Pada Siswa SMP Se Kota Yogyakarta", Jurnal Informasi Kajian Ilmu Komunikasi Vol. 47, No. 1.

Zuhairini. (2004). Metodologi Pembelajaran Pendidikan Agama Islam. Malang: UIN Press. 